\title{
TEACHERS' ATTITUDE TOWARDS REMOTE LEARNING: ANALYSIS OF LATVIA'S CASE
}

\author{
Svetlana Usca \\ Rezekne Academy of Technologies, Latvia \\ Janis Dzerviniks \\ Rezekne Academy of Technologies, Latvia \\ Velta Lubkina \\ Rezekne Academy of Technologies, Latvia \\ Aija Vindece \\ Rezekne Academy of Technologies, Latvia \\ Janis Poplavskis \\ Rezekne Academy of Technologies, Latvia
}

\begin{abstract}
The virtual environment has broken into all areas of our lives in the 21st century. Consequently, the issue of using IT at different levels of education, the usefulness or harmfulness of technologies, as well as the readiness of teachers to work with them is becoming more and more important. The Covid-19 pandemic activated the "technology revolution", and Latvia's educational institutions switched to remote learning. Such a transformation revealed the strengths and weaknesses of education, as well as raised the issue of teachers' readiness for work in remote learning and attitude towards rapid change.

The paper analyzes the data obtained by the State Research Programme "Life with COVID19: Evaluation of overcoming the coronavirus crisis in Latvia and recommendations for social resilience in the future (CoLife)" on the attitude of Latvia's teachers towards the remote learning process.

Research method: online survey of 559 general education teachers (K-12).
\end{abstract}

Keywords: remote learning process, digital competence, teachers, provision of support.

\section{Introduction}

The COVID-19 pandemic created an urgent need for global and unplanned changes in the organization of the education process: remote learning has become a global phenomenon (Hodges, Moore, Lockee, Trust, \& Bond, 2020; Sokal, Trudel, \& Babb, 2020) and an integral part of general education when a traditional school began to transform into an online and virtual school. The introduction of remote learning raised the issue of the need to identify available and used digital solutions in education and promoted digital transformation in education, which is an important process of change based on changes in content, organizational forms, 
methods, and teaching aidsfor work in the digital educational environment. Both the teacher's knowledge and skills and a positive attitude are important in the introduction of change. Researches on the competence of teachers to organize the remote learning process (Romero-Tena et al., 2020, Kong, Lai, \& Sun, 2020; Seufert, Guggemos, \&Sailer, 2021) focus on the development of pedagogical digital competence, less analysis is given to attitude that is an important factor for the quality use of technology in the educational process, as it indicates the acceptance of technology and the intention to use it for the implementation of a quality learning process (Scherer \&Teo, 2019). Attitude towards change can be seen in 3 dimensions:

1) cognitive responses - teachers' belief in the importance and necessity of change and the extent to which it will benefit them personally and in the organizational context;

2) emotional responses - teachers' satisfaction or anxiety about change;

3) behavioural responses - actions for or against change, i.e. the extent to which teachers support or resist change (Kin \&Kareem, 2017).

People who do not believe in the benefits of change are more likely to oppose it. In the case of the COVID-19 pandemic, there were different cognitive responses to the transition to online learning. In Latvia, discussions on remote learning took place in both the first and second waves of the Covid-19 pandemic, which emphasized concerns about quality, possible reductions in the number of teachers, etc.

The aim of the paper: to analyze the data obtained by the State Research Programme "Life with COVID-19: Evaluation of overcoming the coronavirus crisis in Latvia and recommendations for social resilience in the future (CoLife)" on the attitude of teachers towards the remote learning process in Latvia.

\section{Methodology}

A survey of general education teachers was conducted to study the attitude of general education teachers towards remote learning. As the survey took place online and in a short period of time, coinciding with the beginning of the school year and the introduction of the competency approach in general education, we assume that the most active teachers and those who are "in good relations" with the Internet participated in the survey. 559 general education teachers $(\mathrm{K}-12)$ from all regions of Latvia filled in the questionnaire: Riga - 17\%, Kurzeme - 11.4\%, Vidzeme - 32.2\%, Zemgale - 6.3\%, Latgale - 30.1\%. 14.7\% of respondents work in pre-school education level, 3.5\% of respondents work in primary education stage I (Forms 1-6), 24.2\% of respondents work in primary education stage II (Forms $7-9$ ) and $26.7 \%$ of respondents work in secondary school. $64.8 \%$ of respondents have their main job in schools located in regional cities, $18.2 \%$ of 
respondents work in rural schools, the rest - in Riga. Using the Raosoft calculation (http://www.raosoft.com/samplesize.html), we see that the number of respondents exceeds the minimum recommended size. In turn, the Cronbach's alpha coefficient $(\alpha=.955)$ indicates the internal consistency of the questionnaire and the stability of measurements over time. Respondents were asked to express their views on the proposed statements and answer the open-ended questions. The Likert scale was used to evaluate the statements, where 1 means disagree, 2 rather disagree, 3 - rather agree and 4 - agree.

The questionnaire included statements (Table 1) that cause teachers' cognitive response (CR) and emotional response (ER).

Table 1 Statements that Cause Cognitive and Emotional Responses

\begin{tabular}{|c|c|c|}
\hline Code & & Statement \\
\hline \multirow{7}{*}{ 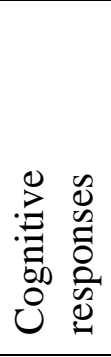 } & KR_1 & Very useful experience for both teachers and children/pupils \\
\hline & KR_2 & Reveals both strengths and weaknesses in the education system \\
\hline & KR_3 & Challenge not only for teachers, but also for parents and pupils \\
\hline & KR_4 & It promotes professional development \\
\hline & KR_5 & Each pupil is provided with an individual approach \\
\hline & KR_6 & It develops the ability to learn \\
\hline & KR_7 & Digital skills of teachers and pupils are improving \\
\hline \multirow{7}{*}{ 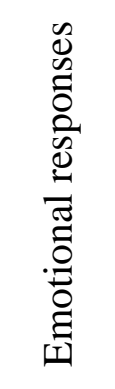 } & ER_1 & Learning process is of lower quality \\
\hline & ER_2 & $\begin{array}{l}\text { It is more difficult to organize the learning process (methods and forms } \\
\text { of work cannot be changed flexibly) }\end{array}$ \\
\hline & ER_3 & Pupils develop more independence \\
\hline & ER_4 & It is difficult for a teacher to perceive pupil's emotions \\
\hline & ER_5 & Lower communication quality \\
\hline & ER_6 & More online learning materials are needed \\
\hline & ER_7 & Lack of technical means (computers, etc.) \\
\hline
\end{tabular}

\section{Results and Their Interpretation}

The average evaluations of the statements and the distribution of answers as a percentage are shown in Table 2 .

In the results of the statements related to cognitive responses, there were statistically significant differences depending on the respondents' length of service in the assessment of KR_2 statement $(\mathrm{p}=.028)$ : respondents with a length of service of up to 5 years (Mean 3.51) and 10 to 14 years (Mean 3.33) agree more, respondents with a length of service over 20 years agree less (Mean 3.19). There were also statistically significant differences in this statement depending on the age of the respondents ( $\mathrm{p}=.048)$ : respondents under 25 years of age (Mean 3.52 ) and from 26 to 35 years of age (Mean 3.42) agree more, respondents in the age from 36 to 45 years (Mean 3.19) and 46 to 55 years (Mean 3.17) agree less. 
As the block of questions on attitude used the questions of the surveys of the Independent Education Society (hereinafter - IES), which took place in the end of the school year 2019/2020, comparison was made whether the teachers' answers showed the same tendencies (nra.lv, 03.06.2020).

Table 2 Respondents' Attitude Towards Remote Learning

\begin{tabular}{|c|c|c|c|c|c|c|}
\hline & \multirow[t]{2}{*}{ Code } & \multirow[b]{2}{*}{ Average } & \multicolumn{4}{|c|}{ Percentage } \\
\hline & & & Disagree & $\begin{array}{c}\text { Rather } \\
\text { disagree }\end{array}$ & $\begin{array}{c}\text { Rather } \\
\text { agree }\end{array}$ & Agree \\
\hline \multirow{7}{*}{ 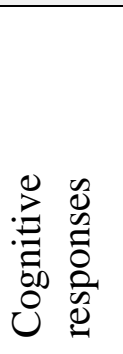 } & KR_1 & 3,19 & 2,3 & 10,0 & 54,4 & 33,3 \\
\hline & KR_2 & 3,25 & 2,0 & 11,1 & 47,4 & 39,5 \\
\hline & KR_3 & 3,66 & 0,7 & 2,3 & 27,2 & 69,8 \\
\hline & KR_4 & 3,16 & 3,8 & 14,5 & 43,8 & 37,9 \\
\hline & KR_5 & 2,48 & 11,8 & 41,3 & 34,3 & 12,5 \\
\hline & KR_6 & 2,99 & 3,0 & 20,9 & 49,7 & 26,3 \\
\hline & KR_7 & 3,36 & 1,1 & 7,5 & 45,6 & 45,8 \\
\hline \multirow{7}{*}{ 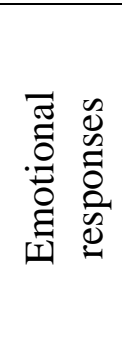 } & ER_1 & 2,69 & 7,3 & 34,9 & 39,7 & 18,1 \\
\hline & ER_2 & 2,96 & 5,5 & 17,5 & 52,2 & 24,7 \\
\hline & ER_3 & 3,05 & 2,3 & 18,6 & 51,0 & 28,1 \\
\hline & ER_4 & 3,9 & 2,1 & 10,9 & 42,9 & 44,0 \\
\hline & ER_5 & 3,08 & 4,7 & 19,7 & 38,6 & 37,0 \\
\hline & ER_6 & 3,48 & 2,1 & 4,8 & 35,4 & 57,6 \\
\hline & ER_7 & 3,22 & 4,7 & 14,8 & 34,0 & 46,5 \\
\hline
\end{tabular}

In the SRP survey, 39.5\% of respondents agree with the statement that remote learning revealed both strengths and weaknesses in the education system, while $47.4 \%$ of respondents rather agree with this statement (52.1\% and 35.5\% in the IES survey, respectively). $69.8 \%$ of respondents agree with the statement that remote learning was a challenge not only for teachers, but also for pupils and parents, but $27.4 \%$ of respondents rather agree with such a statement $(88.6 \%$ and $11 \%$ in the IES survey, respectively). $45.8 \%$ of respondents indicate that they agree that remote learning improved the digital skills of teachers and pupils, $45.6 \%$ rather agree with this statement (65\% and 33.3\% in the IES survey, respectively). Despite the fact that the IES survey was conducted at a different time and responded to by other respondents, we can conclude that the trend persists. Although teachers understand the need for change on a cognitive level, they can resist it emotionally because change creates stress that is intensified by other aspects of the crisis.

In the results of the statements related to the assessment of emotional responses, we see that ER_1 - 57.8\%, ER_2 - 76.9\%, ER_3 - 79.1\%, ER_4 86.9\% and ER_5 - 75.6\% of respondents rather agree and agree with the statements, which indicate dissatisfaction and anxiety about the quality of the 
educational process, as well as the level of individual competence for remote learning. Statistically significant differences were also found depending on the age of respondents in the assessments of the statement AR_1 ( $p=.029)$. Respondents aged 26 to 35 (Mean 2.91) and those older than 55 (Mean 2.72) agree more with the statement, and respondents aged 36 to 45 (Mean 2.56) agree less.

The assessment of ER_1 shows that teachers feel bad about the quality of their work because: 1) transformation requires the use of new organizational forms, methods, teaching aids, but most of teachers have insufficient experience in this field, since they used technology only to show a video before; 2) teachers, who have proven their professionalism in classroom training, feel confused and concerned about professionalism in the virtual environment; 3) insufficient range of digital learning tools creates stress and additional workload. The level of teachers' personal digital competence causes additional stress and dissatisfaction. In the survey conducted by the Ministry of Education and Science in the spring of 2020, one third of teachers admitted that they have no experience in using digital platforms and systems, and about a quarter of teachers did not teach any lessons online. In addition, $14 \%$ of teachers believe that it would take a long time to acquire such knowledge (Škietniece, 2020). Analyzing the attitude of teachers towards the remote learning process, which was revealed in the open-ended questions, it can be concluded that it was a new form of pedagogical work for most teachers, respondents had no previous experience, which created additional tension. Due to the lack of digital competence, teachers experience so-called technostress (Al-Fudail \& Mellar, 2008) - a situation where technology has to be used to support the learning process, but the individual faces an internal (e.g. skills and experience in working with digital tools and platforms) or an external barrier (e.g. lack of technical support highlighted by respondents in the open-ended questions). Insufficient technical means also cause stress (80.5\% of respondents rather agree and agree with the statement ER_7). This aspect has also been emphasized in other researches (Škietniece, 2020; Harris, 2020). The lack of technical means, as well as insufficient support for pupils in their use, creates inequalities in the acquisition of content. As the pandemic continues, persistent dissatisfaction with the quality of the learning process, individual digital competence, lack of technical and teaching resources and workload can lead to professional burnout. Teachers who burn out have more conflicts with learners, pupils achieve lower results (Collie \& Martin, 2017).

Cognitive and emotional responses affect behavioural responses. The analysis of the open-ended questions shows that teachers inLatvia are determined, ready to accept changes and improve their professional work in the virtual environment: "Teachers need to learn to feel comfortable in the digital environment, because then, in principle, the possibilities are limitless", "... the attitude must be changed. You cannot just sit and wish, wait for someone to teach, 
provide for, give, etc., you have to start doing it yourself", "...you have to be flexible, understanding and patient. I think the first "crisis situation" was a good experience, and we will all be more prepared in the future".

Answering the open-ended questions of the questionnaire and analyzing the experience during the first wave of COVID-19 and looking for solutions to improve the remote learning process, teachers identify 4 levels that need to be improved: individual, educational institutional, municipal and national (Figure 1).

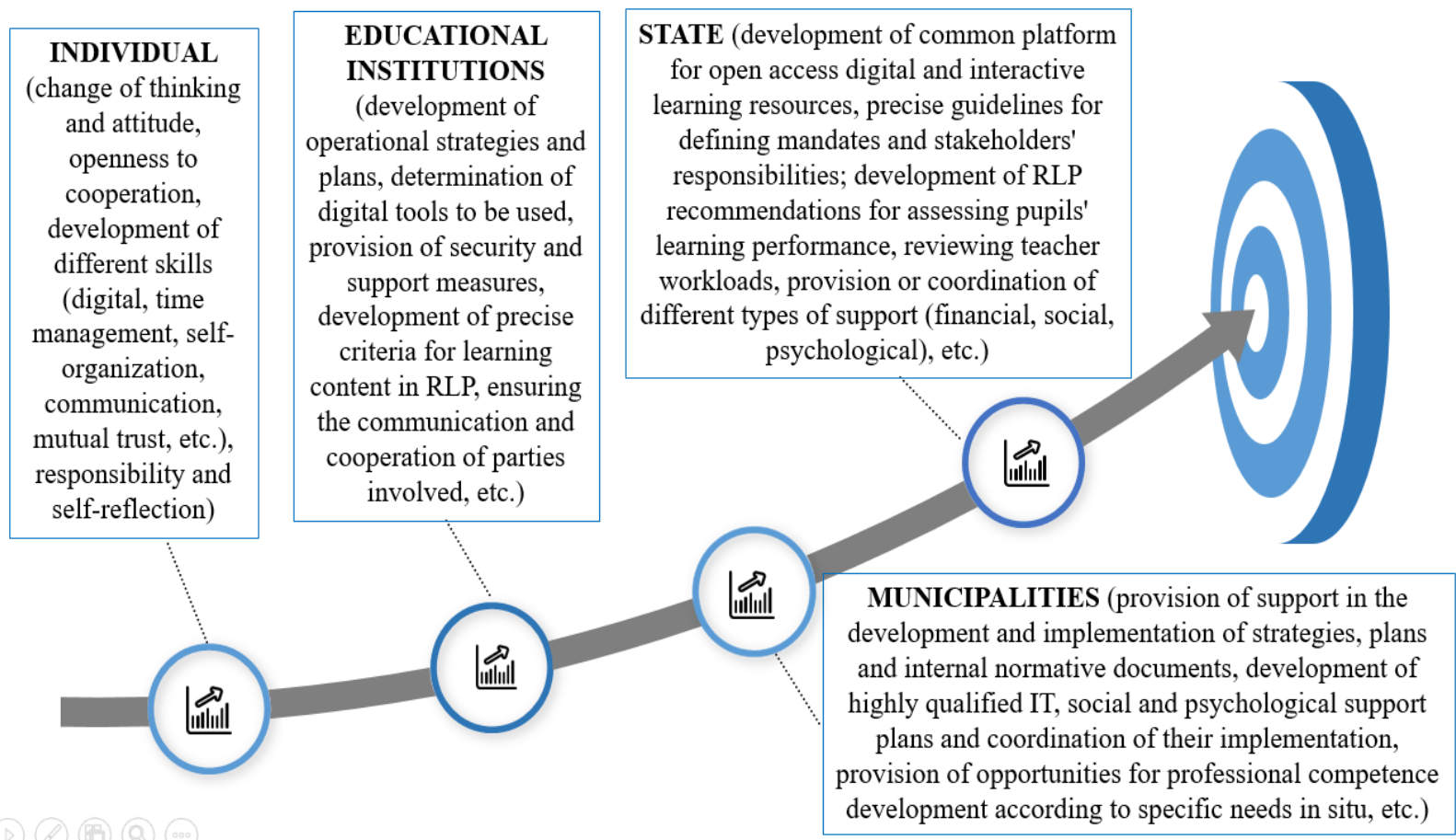

Figure 1 Teachers' Vision for the Improvement of the Remote Learning Process

\section{Conclusions and Recommendations}

The remote learning process launched during the Covid-19 pandemic revealed the strengths and weaknesses of Latvian education and was a challenge for all parties involved. The implementation of the teachers' recommendations identified in the survey at the individual level indicates the readiness of teachers for change, implementation at the highest levels (educational institutional, municipal and national level) is support for teachers during changes; the result is the remote learning process of a higher quality.

At the individual level, teachers consider the following actions as the most important:

1. to improve the ability to adapt to the current situation and requirements by changing the paradigm of thinking; 
2. to observe consistency and work in accordance with the algorithm and procedure for the implementation of remote learning developed by an educational institution;

3. to develop professional competence (digital, time management, selforganization, assessment, communication, mutual trust, etc.) to personalize the learning process, ensure individualization and differentiation and be able to provide meaningful feedback.

At the level of an educational institution, teachers emphasize the need:

1. for school management representatives to work together as a team, learning and using change management techniques and developing clear algorithms for crisis management, creating a common platform for communication between school management, teachers, pupils and parents, thus ensuring mutual cooperation and quality communication, as well as providing a unified school's approach to ensure the learning process.

2. to define the requirements of teaching sessions and follow their fulfilment, paying attention to the fact that lessons include:

- $\quad$ a certain form; results to be achieved by a lesson, resources and information to be used, tasks, and evaluation criteria are precisely defined;

- $\quad$ various activities according to different types of perception (for example, reading, formulation of ideas, debates, group work, writing, animation, audio, video material, etc.);

- $\quad$ activities for the development of self-directed and learner-centered learning process;

- $\quad$ emphasis that is placed on research of pupils' own attitudes and values, integrating topics/events relevant to pupils into the content of lessons, their knowledge is facilitated by short tests, thus reducing emotional distance;

- feedback that is focused on the pupil's self-development; its regularity is updated.

At the municipal level, it is necessary to:

1. create a centralized IT centre for the creation, maintenance and supervision of high-quality technical infrastructure of educational institutions, ensuring data security requirements;

2. develop a mechanism and provide qualified social and psychological support measures to all parties involved. It is important to determine the role of social services during an emergency situation (support for families), how social assistance is provided in educational institutions 
and in cooperation with local governments, providing support for lowincome and large families (IT support, free lunches, etc.);

3. provide support to educational institutions in the development of remote learning implementation strategies, plans and internal normative documents, manage the technical and management resources of educational institutions and monitor regularly the implementation of remote learning in educational institutions established by a municipality;

4. organize and coordinate the mutual cooperation of the heads of educational institutions in a municipality, the implementation of a unified approach in educational institutions at the municipal level, and the professional development of the heads of educational institutions in change management;

5. strengthen partnerships with higher education institutions by involving their specialists in providing support to teachers of educational institutions, and students - in providing support to pupils, parents and teachers in the implementation of remote learning and participating in the development of methodological and interactive teaching materials.

At the national level, respondents would like to see the following actions:

1. the successful implementation of remote learning requires the cooperation of several ministries (Education, Economy, Welfare, Finance) and public and private sector institutions in order to:

- $\quad$ reduce regional disparities, find means to improve infrastructure (improve the technical provision of educational institutions, especially in pre-schools, and access to quality Internet, technologies, etc.);

- address issues related to the educational process (professional development of teachers, development of appropriate materials) effectively and ensure high-quality information flow at the municipal and national level, defining the responsibilities of municipalities, institutions, teachers, parents, etc .;

- $\quad$ provide psychological, social and technical support to families.

2. it is necessary to provide a secure unified digital free learning platform that would be user-friendly, so that it can be used independently by the 1st stage learners of elementary education without the support of parents, in which:

- teaching materials would be uploaded in accordance with standards and curricula, as well as in accordance with the specifics of the remote learning process at all levels of education; 
- $\quad$ differentiated teaching materials would be included according to the abilities of learners;

- $\quad$ information would be available on secure (including free) websites where applications are available, additional information on the content to be learned and ideas for planning and implementing the learning process, as well as instructions for safe installation and use of various programmes;

3. to provide opportunities to supplement the content of the learning platform with materials developed and tested by practicing teachers regularly, the compliance and quality of which is assessed by a specialist in accordance with the established criteria, respecting copyright and providing financial coverage (royalties) for material developers;

4. to incorporate the remote learning elements into the daily learning process, developing digital skills and adaptability to work in different situations, in order to reduce stress and confusion during a crisis and to improve learners' self-directed learning skills. It is suggested to find an opportunity for educational institutions to determine the number of remote learning days per month for each level of education in which pupils learn remotely. The number of days is increased in proportion to the level of education, for example, 1 day a month in preschool, 2-3 days a month in stage I of primary school, 3-4 days a month in stage II of primary school, and at least 1 day a week in secondary school;

5. the MES should review the workload of teachers and pupils during remote learning, develop regulations on working time, pay, and the amount of compulsory learning content;

6. to evaluate the possibility to develop sample curricula of subjects and/or methodological recommendations for work during emergency situations.

\section{Acknowledgement}
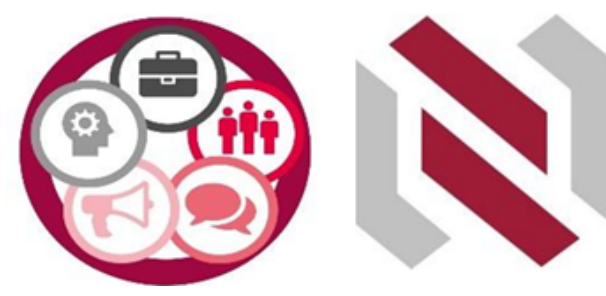

This article was supported by the State Research programme project "Life with COVID-19:

Evaluation of overcoming the coronavirus crisis in Latvia and recommendations for societal resilience in the future" (CoLife) Nr. VPP-COVID-2020/10013 
Usca et al., 2021. Teachers' Attitude Towards Remote Learning: Analysis of Latvia's Case

\section{References}

Al-Fudail, M. \& Mellar, H. (2008). Investigating teacher stress when using technology. Computers \& Education, 51(3), 1103-1110. DOI: https://doi.org/10.1016/ j.compedu.2007.11.004

Collie, R.J. \& Martin, A.J. (2017). Teachers' sense of adaptability: Examining links with perceived autonomy support, teachers' psychological functioning, and students' numeracy achievement. Learning and Individual Differences, 55, 29-39. DOI: https://doi.org/10.1016/j.lindif.2017.03.003

Este, J. (2020). Coronavirus: Distance learning poses challenges for some families of children with disabilities. The Conversation. Retrieved from https://theconversation.com/ coronavirus-distance-learning-poses-challenges-for-some-families-of-children-withdisabilities-136696

Harris, S. (2020). How to prevent teacher burnout during the corona virus pandemic. The Conversation. Retrieved from https://theconversation.com/how-to-prevent-teacherburnout-during-the-coronavirus-pandemic-139353

Hodges, C., Moore, S., Lockee, B., Trust, T., \& Bond, A. (2020). The difference between emergency remote teaching and online learning. Retrieved from https://medicine.hofstra.edu/pdf/faculty/facdev/facdev-article.pdf

Kin, T.M. \& Kareem, O.A. (2017). Measuring teacher attitudes toward change: An empirical validation. International Journal of Management in Education, 10(1), 1-23. DOI: 10.1504/IJMIE.2017.10005987

Kong, S-C., Lai, M., \& Sun, D. (2020). Teacher development in computational thinking: Design and learning outcomes of programming concepts, practices and pedagogy. Computers \&Education, 151. DOI: https://doi.org/10.1016/j.compedu.2020.103872

nra.lv (03.06.2020). Aptauja: lielākā dal̦a pedagogu uzskata, ka esošā situācija ir grūdiens pārmain̄ām. Retrieved from https://nra.lv/latvija/izglitiba-karjera/316064-aptaujalielaka-dala-pedagogu-uzskata-ka-esosa-situacija-ir-grudiens-parmainam.htm

Romero-Tena, R., Barragán-Sánchez,R., Llorente-Cejudo, C., \& Palacios-Rodríguez, A. (2020). The Challenge of Initial Training for Early Childhood Teachers. A Cross Sectional Study of Their Digital Competences. Sustainability, 12(11), DOI: https://doi.org/10.3390/su12114782

Scherer, R., \& Teo, T. (2019). Unpacking teachers' intentions to integrate technology: A metaanalysis. Educational Research Review, 27, 90-109. DOI: https://doi.org/10.1016/ j.edurev.2019.03.001

Seuferta, S., Guggemos, J., \& Sailer, M. (2021). Technology-related knowledge, skills, and attitudes of pre- and in-service teachers: The current situation and emerging trends. Computers in Human Behavior, 115. DOI: https://doi.org/10.1016/j.chb.2020.106552

Sokal, L., Trudel, L. E., \& Babb, J. (2020). Canadian teachers' attitudes toward change, efficacy, and burnout during the COVID-19 pandemic. International Journal of Educational Research Open, 1. DOI: https://doi.org/10.1016/j.ijedro.2020.100016

Šķietniece, I. (2020). Vai mācības attālināti ietekmē izglītības kvalitāti? Skolas Vārds, 14 (179), 3-6. Retrieved from file://C:/Users/user/Downloads/Skolas_Vards_Nr_14_2020.pdf 